\title{
Spawalność wysokowytrzymałych stali wielofazowych AHSS
}

\section{Weldability of high-strength multiphase AHSS steels}

\section{Streszczenie}

W artykule dokonano przeglądu wysokowytrzymałych stali AHSS stosowanych w motoryzacji na odpowiedzialne elementy struktury nośnej samochodów. Przeanalizowano zasady projektowania składu chemicznego i mikrostruktury stali wielofazowych typu DP, TRIP i CP, a także właściwości mechaniczne $\mathrm{i}$ technologię wytwarzania blach. Scharakteryzowano metody łączenia blach cienkich dla motoryzacji. Szczególną uwagę poświęcono spawalności stali AHSS, wskazując na główne trudności technologiczne występujące podczas zgrzewania oporowego i spawania laserowego. Artykuł uzupełniono wynikami badań własnych spawalności stali CP i TRIP.

Słowa kluczowe: stal wysokowytrzymała, właściwości

\section{Abstract}

The review of advanced high-strength AHSS steels used in automotive industry for important elements of the body-in-white has been presented in the paper. The principles of the design of chemical composition and microstructure of multiphase DP, TRIP and CP-type steels as well as mechanical properties and manufacturing technology of sheets have been analysed. Joining methods used for automotive steel sheets have been characterized. The special attention has been paid to weldability of AHSS steels with indicating major technological problems occurring during their resistance spot welding and laser welding. The paper contains some authors' results on weldability of CP and TRIP steels.

Keywords: high-strength steel, properties

\section{Wstęp}

Rosnące ceny źródeł energii oraz względy ekologiczne zmuszają koncerny samochodowe do redukcji zużycia paliwa produkowanych pojazdów. Podstawowym sposobem osiągnięcia tego celu jest redukcja masy własnej samochodu. Aby to osiągnąć, producenci poszukują nowych gatunków materiałów, zarówno na elementy struktury nośnej, jak i poszycia. W ostatniej dekadzie dokonał się znaczący postęp w opracowaniu i wytwarzaniu nowoczesnych gatunków stali na różnorodne elementy nadwozia i podwozia samochodów. Obserwuje się dynamiczny wzrost udziału stali wysokowytrzymałych AHSS (Advanced High-Strength Stee/s), umożliwiających redukcję grubości stosowanych blach stalowych, a tym samym zmniejszenie zużycia paliwa i emisji spalin emitowanych do otoczenia. Nowoczesne stale cechują się wielofazową mikrostrukturą, która zapewnia równowagę pomiędzy właściwo- ściami wytrzymałościowymi i plastycznymi, a blachy stalowe wykazują dobrą podatność na kształtowanie technologiczne.

Do niedawna dominujący udział $w$ konstrukcji aut miały blachy ze stali głęboko tłocznych o strukturze ferrytycznej (miękkie). W zakresie większych wytrzymałości stosowano głównie stale HSLA (High Strength Low Alloy) zawierające mikrododatki $\mathrm{Nb}, \mathrm{Ti}$ i/lub $\mathrm{V}[1,2]$. W zależności od zawartości węgla i rodzaju obróbki cieplnej stale te mają strukturę umocnionego ferrytu, ferrytyczno-perlityczną, ferrytyczno-bainityczną, bainityczną lub martenzytu odpuszczonego. Głównym ograniczeniem stosowania stali HSLA jest malejąca plastyczność blach wraz ze wzrostem wytrzymałości. Barierę tę pokonują stale AHSS o mikrostrukturze wielofazowej, które dzięki oddziaływaniu pomiędzy miękkimi i twardymi składnikami strukturalnymi łączą wysoką

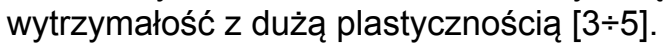

Dr hab. inż. Adam Grajcar, prof. PŚı - Politechnika Śląska, Gliwice; dr inż. Maciej Różański - Instytut Spawalnictwa w Gliwicach. 
Istotny wkład w rozwój wysokowytrzymałych blach stalowych dla motoryzacji wniosły projekty międzynarodowe z udziałem licznych firm przemysłu stalowniczego i sektora samochodowego. Optymalizacja masy nadwozia i podwozia samochodów nie byłaby możliwa bez kompleksowego podejścia obejmującego zarówno zastosowanie stali AHSS, jak i nowoczesnych metod kształtowania elementów oraz innowacyjnych technologii łączenia poszczególnych zespołów karoserii [6]. W zakresie łączenia blach dla motoryzacji dominujące znaczenie ma nadal zgrzewanie punktowe rezystancyjne, chociaż często wykorzystuje się także spawanie laserowe, łukowe, zgrzewanie prądami wysokiej częstotliwości oraz lutospawanie. Łączenie stali AHSS nie wymaga stosowania specjalnego oprzyrządowania technologicznego. Jednak, ze względu na podwyższoną zawartość $C$ oraz dodatków stopowych w porównaniu ze stalami miękkimi i HSLA, ich łączenie wymaga stosowania dodatkowych zabiegów oraz modyfikacji parametrów procesu.

\section{Rodzaje wysokowytrzymałych stali AHSS}

\section{Skład chemiczny stali AHSS}

$\mathrm{Na}$ elementy poszycia stosowane są zwykle stale miękkie, typu IF (Interstitial Free) i BH (Bake Hardenable), opisane szczegółowo w $[7,8]$. Wysokowytrzymałe stale AHSS zastępują stopniowo HSLA, stosowane na liczne elementy struktury nośnej nadwozia samochodu. Spośród stali wielofazowych AHSS najczęściej używane są stale DP (Dual Phase) o strukturze ferrytyczno-martenzytycznej $[3,6,8]$. Wynika to $z$ dobrego połączenia właściwości wytrzymałościowych i odkształcalności technologicznej blach, a także relatywnie prostej metody ich wytwarzania oraz niewielu problemów przy ich przetwórstwie i łączeniu.

Tablica I. Typowe składy chemiczne stali AHSS, \% wag. Table I. Typical chemical compositions of AHSS steels, wt.\%

\begin{tabular}{|c|c|c|c|c|c|c|c|}
\hline $\begin{array}{c}\text { Typ } \\
\text { stali }\end{array}$ & $\mathrm{C}$ & $\mathrm{Mn}$ & $\mathrm{Si}$ & $\mathrm{Al}$ & $\mathrm{Mo}$ & $\mathrm{Cr}$ & Inne \\
\hline DP & 0,10 & 1,50 & 0,25 & - & - & 0,8 & - \\
\hline \multirow{2}{*}{ TRIP } & 0,20 & 1,50 & 1,50 & - & - & - & - \\
\cline { 2 - 8 } & 0,24 & 1,50 & 0,25 & 1,50 & 0,15 & - & - \\
\hline CP & 0,15 & 1,50 & 0,25 & - & 0,20 & 0,30 & $\mathrm{Ti}, \mathrm{Nb}, \mathrm{B}$ \\
\hline
\end{tabular}

Ze względu na zapewnienie dobrej spawalności są to stale niskowęglowe zawierające $0,08 \div 0,15 \% \mathrm{C}$, $1,2 \div 2 \%$ Mn i $0,15 \div 0,5 \%$ Si. W celu poprawy hartowności stosowany jest $\mathrm{Cr}$ i Mo o łącznej zawartości $0,2 \div 0,8 \%$. Typowy skład chemiczny stali DP zestawiono $w$ tablicy I, natomiast na rysunku 1 porównano schematycznie zakres stężenia $\mathrm{C}$ i dodatków stopowych stosowanych w stalach wielofazowych.

Większą zdolność do kształtowania technologicznego mają blachy ze stali TRIP o strukturze ferrytycznej z równomiernie rozmieszczonymi wysepkami bainityczno-austenitycznymi. Przykładowe składy chemiczne stali TRIP przedstawiono w tablicy I. Projektowanie składu chemicznego w tych stalach podporządkowane jest przede wszystkim możliwości stabilizacji do ok. 15\% austenitu szczątkowego, gwarantującego wykorzystanie zalet wywołanej przez odkształcenie przemiany martenzytycznej. Z tego względu zawartość $C$ - będącego podstawowym pierwiastkiem stabilizującym auste-

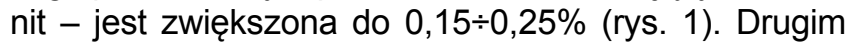
pierwiastkiem austenitotwórczym jest $\mathrm{Mn}$, dodawany w stężeniu do ok. $2 \%$. Istotne znaczenie dla stabilizacji austenitu szczątkowego ma krzem. Pierwiastek ten należy do grupy pierwiastków grafityzujących i hamuje wydzielanie węglików podczas izotermicznej przemiany bainitycznej. Tak uzyskiwany bainit nie zawiera wydzieleń węglikowych, a węgiel wzbogaca austenit $[7 \div 9]$. Niestety Si powoduje znaczne utrudnienia podczas cynkowania blach, gdyż tworzące się na powierzchni związki nie zapewniają należytej zwilżalności blach przez ciekły cynk. $Z$ tego względu rozwijane są także stale zawierające Al (tabl. I), które ma również pozytywny wpływ na hamowanie wydzielania węglików. Zazwyczaj sumaryczne stężenie Si+Al nie przekracza 1,8\%.

Najlepsze właściwości wytrzymałościowe przy nieco mniejszej plastyczności wykazują stale CP (Complex Phase). Są to stale zawierające drobnoziarnisty ferryt, bainit, martenzyt oraz austenit szczątkowy. Stosowane są najczęściej jako blachy gorącowalcowane, dodatkowo umacniane przez dyspersyjne cząstki węglikoazotków Nb i Ti. Wzrost hartowności zapewniony jest przez $\mathrm{Cr}$ i Mo (tabl. I, rys. 1). Stale te wykazują dużą podatność na pochłanianie energii $w$ warunkach obciążeń dynamicznych [6].

\section{Technologia wytwarzania blach stalowych}

Technologia produkcji blach stalowych o strukturze wielofazowej wymaga precyzyjnego doboru składu chemicznego stali, a także dotrzymania wąskich reżimów technologicznych podczas całego cyklu produkcyjnego.

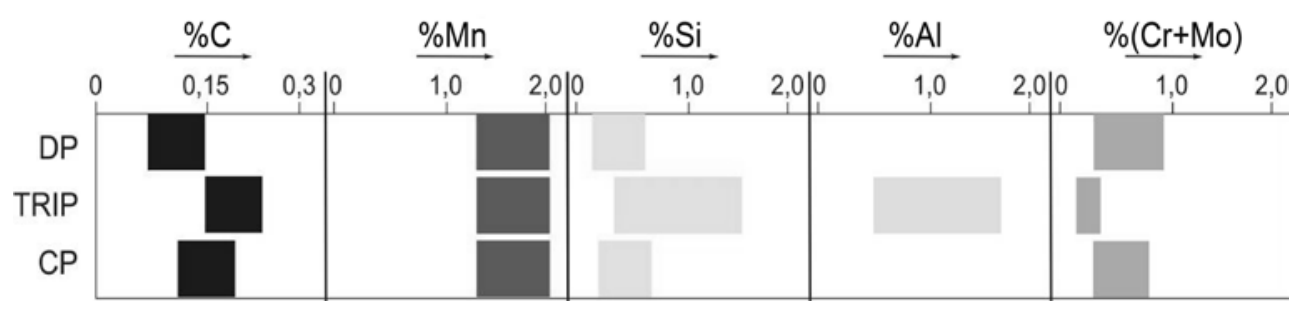

Rys. 1. Porównanie składu chemicznego stali DP, TRIP i CP Fig. 1. Comparison of chemical composition of DP, TRIP and CP steels 
W zależności od przeznaczenia elementu, produkowane są blachy gorącowalcowane i zimnowalcowane o szerokim zakresie właściwości mechanicznych i technologicznych, które mogą być cynkowane lub są niepokrywane. Wybór typu stali i rodzaju taśmy zdeterminowany jest głównie rodzajem rozpatrywanego elementu, jego umiejscowieniem w strukturze samochodu (nadwozie/podwozie, konstrukcja nośna/poszycie, strefa przednia/tylna/boczna), a tym samym wymaganiami odnośnie do właściwości mechanicznych, technologicznych i eksploatacyjnych. Ogólnie zadaniem przedniej strefy konstrukcji nośnej samochodu jest absorpcja energii w przypadku kolizji drogowej. $Z$ tego względu $w$ tej strefie stosowane są elementy kształtowane z blach stalowych DP i TRIP. Z tych stali wytwarza się także liczne elementy nośne w strefie tylnej samochodu oraz wzmacniające dach i podłogę. Strefa boczna powinna chronić kierowcę i pasażerów przed wgniataniem elementów w głąb kabiny. $Z$ tego względu musi cechować się znacznie większą sztywnością i wytrzymałością, przy mniejszej odkształcalności. W tej strefie znajdują zastosowanie głównie elementy kształtowane z blach stalowych CP.

Duża dokładność wymiarowa i wykończenia powierzchni elementów kształtowanych z taśm stalowych walcowanych na zimno powoduje, że są one stosowane na nadwozia. W większości przypadków są to blachy ocynkowane, ale stosuje się też taśmy niepokrywane. Elementy podwozia (obręcze kół, wahacze) ze względu na wymaganą niezawodność, odporność zmęczeniową, żywotność itp. wykonywane są zazwyczaj z blach walcowanych na gorąco.

Istotą wytworzenia blach o strukturze DP jest precyzyjne wykonanie obróbki cieplnej po walcowaniu na zimno. W starszych rozwiązaniach prowadzono wyżarzanie rekrystalizujące $w$ piecach kołpakowych, natomiast nowa technologia obejmuje ciągłe wyżarzanie w zintegrowanych liniach technologicznych obejmujących walcowanie na zimno, trawienie taśm, wyżarzanie i cynkowanie ogniowe. Po zakończeniu walcowania na zimno taśmy stalowe o strukturze ferrytyczno-perlitycznej nagrzewa się nieco powyżej $A_{c 1}$ stali, gdzie tworzy się mikrostruktura ferrytyczno-austenityczna. Temperatura wyżarzania określa stosunek ferrytu do austenitu oraz zawartość C w austenicie, która jest tym większa, im większy jest udział fazy $\alpha$. Taśmy niepokrywane należy chłodzić szybko w celu przemiany austenitu wzbogaconego w węgiel $(0,4 \div 0,6 \%)$ w martenzyt, który następnie można odpuszczać w linii stosowanej do przestarzenia. Taśmy cynkowane ogniowo chłodzi się $\mathrm{z}$ prędkością $15 \div 25^{\circ} \mathrm{C} / \mathrm{s}$ do temperatury ok. $450^{\circ} \mathrm{C}$, w której są zanurzane w kąpieli metalowej. Temperatura $\mathrm{M}_{\text {sy }}$ austenitu jest zazwyczaj niższa od temperatury cynkowania, dlatego przemiana martenzytyczna następuje podczas końcowego chłodzenia taśm do temperatury pokojowej.

W przypadku blach walcowanych termomechanicznie niezbędnym warunkiem uzyskania struktury dwufazowej o pożądanym udziale i morfologii składników strukturalnych jest dostosowanie przebiegu chłodzenia taśm do przemian fazowych wynikających z wykresów przemian austenitu przechłodzonego (CTPc). Duże możliwości kształtowania struktur wielofazowych DP i TRIP występują w przypadku krótkich czasów przemian: ferrytycznej i bainitycznej, przy jednoczesnym opóźnieniu początku przemiany perlitycznej. Przesunięcie przemiany ferrytycznej $w$ lewo następuje wraz ze zwiększoną zawartością Si i Al, a w odwrotnym kierunku oddziałują $\mathrm{C}, \mathrm{Mn}, \mathrm{Cr}$, Mo i mikrododatek $\mathrm{B}$. Po zakończeniu walcowania na gorąco taśma stalowa jest szybko chłodzona laminarnie do zakresu temperaturowego przemiany austenitu w ferryt (ok. $650 \div 700^{\circ} \mathrm{C}$ ), a następnie przez kilka sekund $(3 \div 8 \mathrm{~s})$ jest chłodzona na powietrzu (rys. 2a). W tym czasie następuje przemiana austenitu w ferryt o udziale objętościowym $70 \div 85 \%$, a jednocześnie austenit jest wzbogacany w węgiel analogicznie jak podczas wyżarzania międzykrytycznego dla taśm walcowanych na zimno. W kolejnym etapie $w$ celu uniknięcia przemiany perlitycznej taśmy chłodzone są szybko w sposób laminarny w celu przemiany austenitu wzbogaconego $w$ węgiel $w$ martenzyt. Ze względu na wzbogacenie austenitu w węgiel jego hartowność rośnie, a uzyskany udział martenzytu jest zbliżony do udziału fazy Y przed rozpoczęciem szybkiego chłodzenia.

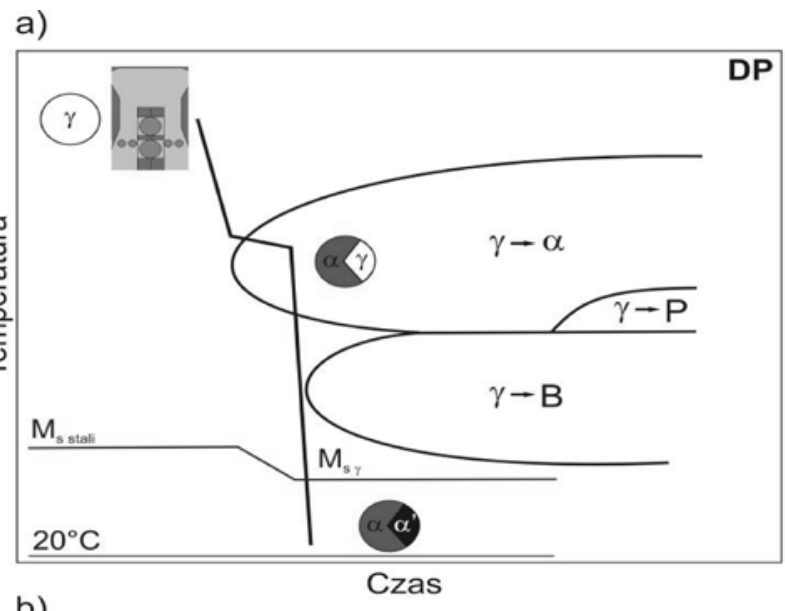

b)

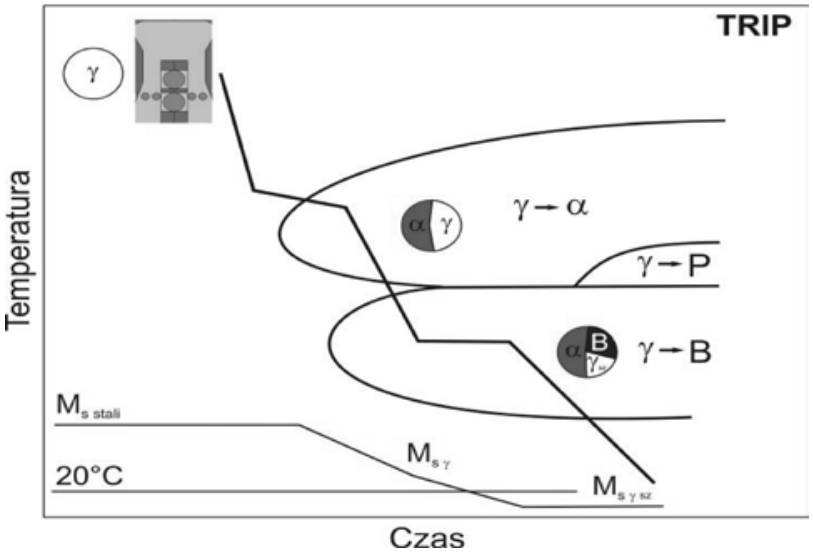

Rys. 2. Przebieg chłodzenia blach po walcowaniu termomechanicznym w celu uzyskania mikrostruktury: a) DP, b) TRIP

Fig. 2. Cooling paths of sheets after thermomechanical rolling to obtain DP-type (a) and TRIP-type (b) microstructures 
Obróbka cieplna stali TRIP jest trudniejsza. Po zakończeniu walcowania na zimno taśmy stalowe o strukturze ferrytyczno-perlitycznej lub ferrytycznoperlityczno-bainitycznej nagrzewa się do zakresu międzykrytycznego $A_{c 1}-A_{c 3}$ i wygrzewa się je w tej temperaturze przez kilka minut. Ze względu na wyższe stężenie C udział ferrytu jest mniejszy niż w przypadku stali DP. Na tym etapie dochodzi także do wzbogacenia austenitu w węgiel do ok. $0,4 \div 0,5 \%$. To stężenie nie gwarantuje jednak obniżenia temperatury początku przemiany martenzytycznej poniżej temperatury pokojowej. $Z$ tego względu dalszy etap obróbki cieplnej obejmuje ochłodzenie taśm do temperatury wytrzymania izotermicznego w zakresie $350 \div 450^{\circ} \mathrm{C}$. Podczas tego zabiegu trwającego od jednej do kilku minut tworzy się ferryt bainityczny, a austenit wzbogacany jest w węgiel do zakresu $1,1 \div 1,4 \%$. Takie stężenie $C$ gwarantuje obniżenie temperatury $\mathrm{M}_{\text {sy }}$ fazy $\mathrm{Y}$, która pozostaje w postaci austenitu szczątkowego o udziale od $10 \div 15 \%$, poniżej temperatury pokojowej [7].

Schemat obróbki cieplnej stosowanej po zakończeniu walcowania na gorąco dla taśm walcowanych termomechanicznie ze stali TRIP przedstawiono na rysunku 2b. Po ostatnim etapie obróbki wykańczającej taśma stalowa jest chłodzona laminarnie z szybkością ok. $100^{\circ} \mathrm{C} / \mathrm{s}$ do temperatury $700^{\circ} \mathrm{C}$. Początkowy przebieg chłodzenia taśm jest podobny jak w przypadku stali DP. Czas na realizację przemiany ferrytycznej wynosi ok. $5 \mathrm{~s}$. Jest on nieco krótszy niż dla stali DP, a wytworzony udział ferrytu jest też mniejszy i wynosi $50 \div 60 \%$. Szczególnie niepożądanym składnikiem strukturalnym w stalach AHSS - zmniejszającym ciągliwość stali - jest perlit. W stalach TRIP absorbuje on węgiel, co uniemożliwia wystarczające wzbogacenie austenitu $\mathrm{w}$ ten pierwiastek. W celu uniknięcia przemiany perlitycznej blachy chłodzone są laminarnie do zakresu przemiany bainitycznej poniżej $500^{\circ} \mathrm{C}$. W tej temperaturze następuje zwijanie taśm w kręgi i dalsze wzbogacenie austenitu w węgiel. Czas wytrzymania nie może być zbyt krótki, gdyż niedostateczne wzbogacenie austenitu w węgiel powoduje przemianę części fazy $\mathrm{Y}$ w martenzyt podczas końcowego chłodzenia blach. Czas ten nie może także być zbyt długi, gdyż powoduje to destabilizację austenitu związaną z wydzielaniem węglików, a następnie z tworzeniem się martenzytu podczas chłodzenia taśm.

Sterowanie temperaturą taśm ze stali CP po zakończeniu walcowania na gorąco jest podobne do stosowanego w przypadku stali TRIP. Czas wolnego chłodzenia w zakresie przemiany austenitu w ferryt jest krótszy, gdyż udział ferrytu nie przekracza zazwyczaj $45 \%$. Także czas wytrzymania izotermicznego w zakresie przemiany bainitycznej jest krótszy. Prowadzi to do wytworzenia ok. $40 \%$ bainitu, a pozostały austenit

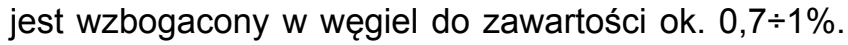
Następuje celowe wytworzenie kilkunastoprocentowego udziału martenzytu podczas końcowego chłodzenia blach do temperatury pokojowej.

\section{Mikrostruktura i właściwości stali AHSS}

Wspólną cechą mikrostruktury stali wielofazowych DP, TRIP i CP jest występowanie miękkiej osnowy ferrytycznej, w której rozmieszczone są umacniające skupiska drugiej fazy o zróżnicowanym składzie strukturalnym. W tym kontekście ich właściwości mechaniczne - podobnie jak w przypadku materiałów kompozytowych będą zależne od udziału i właściwości poszczególnych faz. Największy udział osnowy ferrytycznej i najmniejszy udział wydzieleń występuje zazwyczaj dla stali DP, a następnie proporcje te zmieniają się dla stali TRIP i CP. Typowe stale dwufazowe mają mikrostrukturę, w której drobne skupiska martenzytu są równomiernie rozmieszczone w osnowie ferrytu (rys. 3), przy

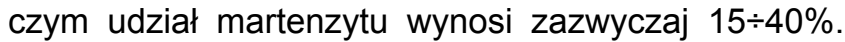
Ferryt stanowi osnowę gwarantującą dobre właściwości plastyczne, natomiast martenzyt jest składnikiem zwiększającym wytrzymałość. Decydujący wpływ na właściwości mechaniczne tych stali ma udział, wielkość i rozmieszczenie wydzieleń martenzytycznych. Charakterystyczną cechą stali DP jest brak wyraźnej granicy plastyczności oraz odkształcenia Lüdersa na krzywej rozciągania. Cechy te są szczególnie ważne dla blach poddawanych tłoczeniu i innym operacjom kształtowania technologicznego. W trakcie końcowego etapu obróbki cieplnej dochodzi do przemiany martenzytycznej austenitu, rozmieszczonego w postaci wysepek w ferrycie. Podczas przemiany martenzytycznej, która wiąże się ze zwiększeniem objętości, wokół martenzytu występuje obszar naprężeń ściskających i generowane są dyslokacje.

Mikrostrukturę stali TRIP stanowi miękka osnowa ferrytyczna, w której rozmieszczone są wysepki bainityczno-austenityczne. Zasadnicze znaczenie ma

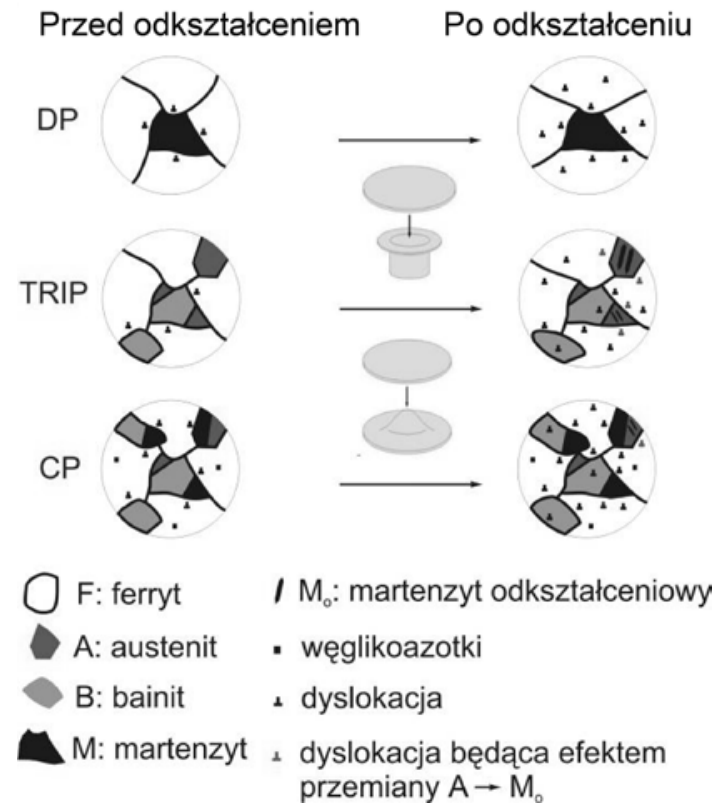

Rys. 3. Schemat mikrostruktury stali DP, TRIP i CP przed odkształceniem plastycznym i po odkształceniu technologicznym na zimno Fig. 3. Schematic of DP, TRIP and CP steel microstructures before plastic deformation and after cold technological forming 
obecność Si lub Si-Al, które hamują wydzielanie węglików podczas wytrzymania blach stalowych w zakresie przemiany bainitycznej. Charakterystyczną cechą stali TRIP jest przemiana martenzytyczna zachodząca podczas tłoczenia, gięcia, obciągania itp. (rys. 3). Przemiana martenzytyczna austenitu szczątkowego zachodzi stopniowo w miarę wzrostu odkształcenia. Przemiana ta - następując w kolejnych miejscach wytłoczki - zapobiega lokalizacji odkształcenia, a jednocześnie prowadzi do silnego umocnienia odkształceniowego. Prowadzi to z kolei do jednoczesnego zwiększenia wytrzymałości na rozciąganie oraz do opóźnienia zapoczątkowania tworzenia się szyjki w próbie rozciągania (oraz pocienienia grubości blachy podczas tłoczenia), a tym samym do uzyskania dużego wydłużenia równomiernego. Stąd pochodzi nazwa TRIP (Transformation Induced Plasticity), tzn. plastyczność wywołana przemianą.

Mikrostruktura stali CP zawiera drobnoziarnisty ferryt, bainit, martenzyt oraz austenit szczątkowy (rys. 3). Dodatkowy wzrost właściwości wytrzymałościowych zapewniony jest przez dyspersyjne wydzielenia węglikoazotków Nb i Ti, podobnie jak w przypadku stali HSLA. Efektywne wykorzystanie tych cząstek do umocnienia następuje podczas obróbki plastycznej na gorąco; z tego względu taśmy te produkowane są w większości jako walcowane termomechanicznie. Stabilność termiczną do temperatury pokojowej zachowuje zazwyczaj kilka procent austenitu szczątkowego.

Przykładowe właściwości mechaniczne stali AHSS zawarto w tablicy II. W rzeczywistości dla danego gatunku stali można uzyskać szeroki zakres właściwości mechanicznych w zależności od warunków zastosowanej obróbki cieplnej lub cieplno-plastycznej. Taśmy ze stali wielofazowych produkowane są pod różnymi nazwami handlowymi [5]. W powszechnej nomenklaturze stosowane są najczęściej oznaczenia: DP 350/600, TRIP 450/700, CP 600/800, co oznacza typ stali oraz minimalną wartość granicy plastyczności i wytrzymałości na rozciąganie. Czasami używa się tylko oznaczeń: DP 600, DP 800, DP 1000 z podaniem wartości $R_{m}$.

Wspólną cechą stali wielofazowych AHSS jest korzystne połączenie wysokiej wytrzymałości i plastyczności. Schematyczne porównanie charakterystyki umocnienia dla stali DP, TRIP i CP o podobnej wartości granicy plastyczności przedstawiono na rysunku 4. Powodem równowagi pomiędzy wytrzymałością i ciągliwością tych stali jest duża wartość szybkości umocnienia odkształceniowego $\mathrm{d} \sigma / d \varepsilon$ podczas odkształcenia

Tablica II. Właściwości mechaniczne typowych stali AHSS [6] Table II. Mechanical properties of typical AHSS steels [6]

\begin{tabular}{|c|c|c|c|c|}
\hline Stal & $\mathrm{R}_{\mathrm{p} 0,2}, \mathrm{MPa}$ & $\mathrm{R}_{\mathrm{m}}, \mathrm{MPa}$ & $\mathrm{A}, \%$ & $\mathrm{n}_{10}{ }^{-} \mathrm{Ag}$ \\
\hline DP 350/600 & 350 & 600 & $24 \div 30$ & 0,16 \\
\hline TRIP 450/800 & 450 & 800 & $26 \div 32$ & 0,18 \\
\hline CP 800/1000 & 800 & 1000 & $8 \div 13$ & - \\
\hline
\end{tabular}

plastycznego na zimno. Ogólnie wynika ona z oddziaływania pomiędzy miękką osnową ferrytyczną i twardymi wydzieleniami, tworzącymi przeszkody dla ruchu dyslokacji. Dodatkowo można wyróżnić inne, charakterystyczne dla danego typu stali czynniki decydujące o przebiegu umocnienia odkształceniowego. W przypadku stali DP decydujące znaczenie dla umocnienia ma obecność dyslokacji występujących wokół wydzieleń martenzytycznych. Dyslokacje te są zdolne do ruchu w początkowym etapie odkształcenia plastycznego, co tłumaczy brak występowania wyraźnej granicy plastyczności na krzywej umocnienia [6]. Obecność twardych skupisk martenzytu decyduje o silnym umocnieniu odkształceniowym stali w początkowym stadium odkształcenia plastycznego (rys. 4), co opóźnia zapoczątkowanie przewężenia próbki w próbie rozciągania oraz pocienienia blach podczas tłoczenia. $W$ rezultacie stale DP cechują się korzystnym połączeniem wytrzymałości i ciągliwości oraz niską wartością ilorazu $R_{p 0,2} / R_{m}$.

Głównym powodem korzystnego połączenia właściwości wytrzymałościowych i plastycznych stali TRIP jest przemiana martenzytyczna austenitu szczątkowego wywołana odkształceniem (rys. 3). Wraz ze wzrostem odkształcenia plastycznego na zimno (np. podczas tłoczenia) w miejscach o dużej koncentracji odkształcenia dochodzi do przemiany dyspersyjnie rozmieszczonych cząstek austenitu w wysokowęglowy martenzyt o dużej wytrzymałości. Duża twardość martenzytu, a także związane z przemianą zwiększenie objętości, przeciwdziałają plastycznej niestabilności próbki wskutek zwiększenia szybkości umocnienia

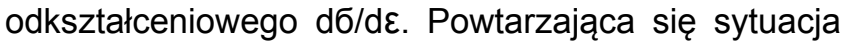
w kolejnych miejscach próbki prowadzi do opóźnienia tworzenia się szyjki w próbce, co skutkuje zwiększeniem wydłużenia równomiernego, a także całkowitego (rys. 4). Ilościowo intensywność umocnienia można wyrazić za pomocą wykładnika umocnienia $\mathrm{n}_{10-\mathrm{Ag}}$, wyznaczanego zazwyczaj w próbie rozciągania w zakresie od odkształcenia $10 \%$ do wydłużenia równomiernego (tabl. II). Przemianie martenzytycznej podlegają największe ziarna fazy $\mathrm{Y}$, podczas gdy mniejsze

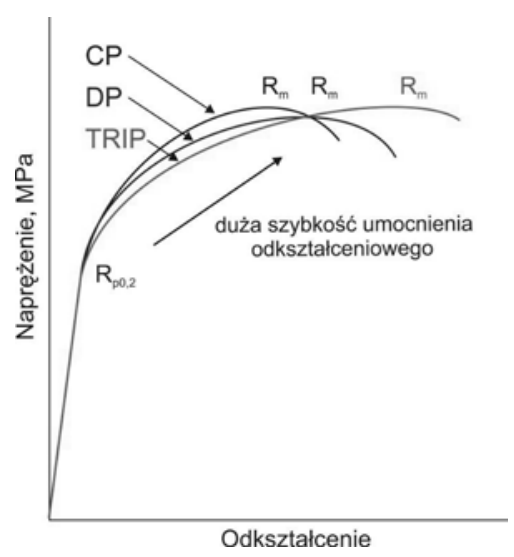

Rys. 4. Porównanie krzywej rozciągania dla stali DP, TRIP i CP o podobnej wartości granicy plastyczności

Fig. 4. Comparison of tensile curves of DP, TRIP and CP steels of a similar yield point 
zachowują stabilność nawet po zerwaniu próbki. Z tego względu nieprzemieniony austenit może być przyczyną dodatkowego umocnienia wytłoczki związanego z przebiegiem efektu TRIP podczas eksploatacji, np.

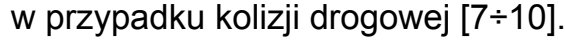

Stale CP umacniają się znacznie w całym zakresie odkształcenia plastycznego (rys. 4) ze względu na znaczny udział przeszkód dla ruchu dyslokacji w postaci wydzieleń bainitycznych i martenzytycznych (rys. 3). Dodatkowe umocnienie pochodzi od dyspersyjnych cząstek węglikoazotków $\mathrm{Nb}$ i Ti, a także od przemiany martenzytycznej wywołanej odkształceniem kilkuprocentowej frakcji austenitu szczątkowego.

\section{Wysokowydajne metody łączenia stali AHSS}

Duża konkurencja na globalnym rynku motoryzacyjnym wymusza na producentach stosowanie bardzo wydajnych procesów produkcyjnych. Zwiększenie wydajności procesów spawalniczych uzyskuje się przez bardzo dużą szybkość nagrzewania elementów metalowych do temperatury ich topnienia lub silnego uplastycznienia oraz dużą szybkość chłodzenia. Obecnie najczęściej stosowaną spawalniczą metodą łączenia elementów metalowych karoserii samochodowych jest zgrzewanie rezystancyjne punktowe. Duży postęp w dziedzinie technologii laserowych spowodował, że zgrzewanie coraz częściej zastępuje się różnymi wariantami spawania wiązką laserową. W pewnych przypadkach, ze względu na prostotę, niski koszt stanowisk spawalniczych oraz małe wymagania dotyczące dokładności przygotowania elementów do spawania, stosowana jest także metoda MAG.

\section{Zgrzewanie rezystancyjne punktowe}

Podczas wytwarzania karoserii samochodu osobowego wykonuje się ok. $7000 \div 12000$ zgrzein punktowych [11]. Znanych jest wiele wariantów zgrzewania rezystancyjnego punktowego, jednak podstawowym i najbardziej rozpowszechnionym procesem stosowanym podczas łączenia elementów karoserii samochodowych jest zgrzewanie rezystancyjne pojedyncze dwustronne. Czas wykonania pojedynczej zgrzeiny przy zastosowaniu parametrów twardych (duża siła docisku elektrody, krótki czas przepływu prądu o wysokim natężeniu) wynosi dla blach o grubości $1 \mathrm{~mm}$ ze stali niestopowej nawet poniżej $0,1 \mathrm{~s}$. Prędkość nagrzewania wynosi wówczas nawet $5 \cdot 10^{4} \mathrm{C} / \mathrm{s}$, a prędkość chłodzenia do $10^{5} \mathrm{C} / \mathrm{s}$ dla grubości blach $0,5 \mathrm{~mm}$ i $2000^{\circ} \mathrm{C} / \mathrm{s}$ dla grubości blach $2 \mathrm{~mm}$ [12].

Ze względu na bardzo dużą wydajność zgrzewania rezystancyjnego punktowego, niski koszt jednostkowy wykonania połączenia, łatwość robotyzacji i automatyzacji oraz bieżącej kontroli parametrów - z możliwością natychmiastowej ich korekty - jest ono metodą bardzo konkurencyjną w stosunku do innych spawalniczych metod łączenia. Ponadto łatwość precyzyjnej regulacji wartości przepływu prądu umożliwia podgrzewanie wstępne lub obróbkę cieplną bezpośrednio po zgrzewaniu, co znacznie rozszerza zakres zastosowania metody o materiały trudniej spawalne. Podstawowymi ograniczeniami metody jest konieczność stosowania dużych docisków powodujących często odkształcenia powierzchni (zmniejszające walory estetyczne), zapewnienie odpowiedniej jakości powierzchni w miejscu styku elektrod z elementami zgrzewanymi oraz konieczność dostępu z obu stron do elementów zgrzewanych. Dodatkowymi ograniczeniami jest konieczność należytego usytuowania zgrzeiny względem siebie (problem bocznikowania prądu) i krawędzi elementów zgrzewanych [13].

\section{Spawanie wiązką laserową}

Spawanie laserowe polega na uzyskaniu połączenia przez stopienie krawędzi materiału łączonego bez lub z dodatkiem spoiwa, w wyniku oddziaływania cieplnego wiązki laserowej. Wiązka laserowa za pomocą światłowodu dostarczana jest do stosunkowo lekkiej głowicy spawalniczej, przeważnie umieszczonej na kiści robota pozycjonującej głowicę względem elementu spawanego. Bardzo duża gęstość mocy $\left(10^{8} \mathrm{~W} / \mathrm{cm}^{2}\right)$ charakterystyczna dla spawania laserowego umożliwia szybkie, punktowe nagrzewanie metalu do temperatury topnienia z prędkością nawet do $10000^{\circ} \mathrm{C} / \mathrm{s}$, a prędkość chłodzenia wynosi $200 \div 5000^{\circ} \mathrm{C} / \mathrm{s}$ [12]. Dzięki tak dużej gęstości mocy spawanie wiązką laserową może być realizowane z prędkością przekraczającą nawet $20 \mathrm{~m} / \mathrm{min}$. Przy tak dużych prędkościach spawania występują jednak pewne ograniczenia. Ograniczeniem technologicznym spawania laserowego jest konieczność precyzyjnego pozycjonowania głowicy laserowej względem elementu spawanego, co przy dużej bezwładności układów zrobotyzowanych narzuca ograniczenia w prędkościach przesuwu głowicy. Ponadto w przypadku konieczności wykonywania złącza doczołowego elementy muszą być dokładnie dopasowane, a trajektoria wiązki laserowej musi przebiegać dokładnie wzdłuż linii złącza. Problemem metalurgicznym jest z kolei bardzo duża szybkość chłodzenia spoiny oraz trudności z zapewnieniem odpowiedniej osłony gazowej, z której w wielu przypadkach się rezygnuje.

Bardzo perspektywiczną, intensywnie rozwijającą się techniką spawania laserowego jest spawanie wiązką skanującą. W tym wypadku wiązka laserowa kierowana jest do obszaru spawania za pomocą ruchomych zwierciadeł znajdujących się w specjalnej głowicy skanującej. Dzięki temu, przy nieruchomej głowicy, możliwe jest bardzo szybkie pozycjonowanie wiązki laserowej (poniżej $30 \mathrm{~ms}$ ) w dowolnym miejscu. Technologia ta pozwala na znaczące zredukowanie czasu wytwarzania elementów, które wykonywane są jako konstrukcje spawane składające się z wielu krótkich spoin o dowolnym kształcie. 


\section{Spawanie metodą MAG}

Spawanie metodą MAG polega na stapianiu spawanego metalu i materiału elektrody topliwej ciepłem łuku elektrycznego jarzącego się pomiędzy elektrodą i spawanym przedmiotem w osłonie gazu aktywnego. Gęstość mocy w tym przypadku wynosi $10^{5} \mathrm{~W} / \mathrm{cm}^{2}$, a więc jest o kilka rzędów wielkości mniejsza niż podczas spawania wiązką laserową. Również szybkość nagrzewania i chłodzenia podczas spawania metodą MAG jest znacząco mniejsza niż przy spawaniu laserowym i wynosi odpowiednio ok. $1500^{\circ} \mathrm{C} / \mathrm{s}$ i $20 \div 300^{\circ} \mathrm{C} / \mathrm{s}$ [12]. Spoina w metodzie MAG tworzona jest w wyniku krystalizacji nadtopionych krawędzi materiału podstawowego wymieszanego ze stopionym drutem elektrodowym. Spoina oraz strefa wpływu ciepła w przypadku spawania metodą MAG są szerokie, a linie wtopienia w materiał podstawowy nie są równoległe. Choć metoda MAG jest znana od końca lat 30 ub.w., to ciągły postęp w dziedzinie elektrotechniki umożliwia jej ciągłą modyfikację. Jedną z takich modyfikacji jest opracowanie urządzeń do spawania niskoenergetycznego umożliwiającego redukcję ilości ciepła wprowadzanego do złącza, a przez to zmniejszenie niekorzystnego efektu oddziaływania cyklu cieplnego spawania na zmiany strukturalne $w$ materiale podstawowym.

\section{Spawalność stali AHSS}

\section{Spawalność stali DP}

Spośród wszystkich stali AHSS o strukturze wielofazowej największe zastosowanie do tej pory znalazły stale dwufazowe. $Z$ tego względu są one także najczęściej przedmiotem badań w zakresie ich spawalności

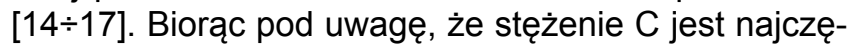
ściej mniejsze od $0,15 \%$, a sumaryczna zawartość dodatków stopowych rzadko przekracza 2,5\%, ich łączenie nie nastręcza większych problemów. Należy jednak pamiętać, że wyjściowa mikrostruktura wielofazowa stali AHSS zgrzewanych oporowo bądź spawanych laserowo ulega zniszczeniu podczas cyklu cieplnego. Ze względu na dużą szybkość chłodzenia złącza są narażone na powstawanie struktur martenzytycznych. Głównym problemem podczas zgrzewania oporowego stali AHSS jest występowanie kruchych pęknięć w płaszczyźnie transkrystalicznej $[4,14,15]$. Problem ten występuje szczególnie dla stali DP o wytrzymałości bliskiej $1000 \mathrm{MPa}$ i większej, zawierających podwyższone stężenie $\mathrm{C}$ i dodatków stopowych. Ponadto Pichler i in. [9] podają, że maksymalna zawartość $P$ w stali w celu uniknięcia pęknięć nie może przekraczać $0,012 \%$.

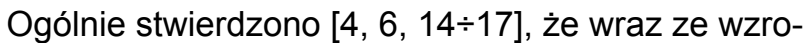
stem wytrzymałości blach ze stali AHSS należy stosować większe siły docisku i średnicę elektrod oraz niższy prąd zgrzewania. Twardość w strefie zgrzeiny wynosi od 300 do 500 HV w zależności od składu chemicznego stali i poziomu wytrzymałości. Często w celu polepszenia plastyczności złącza stosuje się zgrzewanie wieloimpulsowe lub końcowy, prądowy impuls dogrzewający mający na celu odpuszczenie martenzytu. W przypadku blach o wytrzymałości materiału rodzimego bliskiej $1000 \mathrm{MPa}$ lub większej powoduje to jednak obniżenie właściwości wytrzymałościowych złącza.

Istotnym problemem w przypadku blach dla motoryzacji, ocynkowanych ogniowo lub elektrolitycznie, jest zanieczyszczenie powierzchni roboczych i przyspieszone zużycie elektrod, wynikające głównie z niskiej temperatury topnienia i parowania cynku oraz jego skłonności do łączenia się z powierzchnią części roboczych elektrod [18, 19]. Zjawisko to jest nasilone w przypadku blach ocynkowanych z powłokami organicznymi, gdzie wraz ze wzrostem liczby wykonanych zgrzein zmianie ulegają ich budowa i właściwości mechaniczne $[19,20]$. Sposoby przedłużenia trwałości elektrod obejmują m.in. korektę wymiarową ich części roboczej oraz regulację natężenia prądu. Często zgrzewanie rezystancyjne może z powodzeniem być

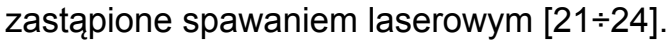

\section{Spawalność stali TRIP}

Biorąc pod uwagę większe stężenie C i dodatków stopowych niż stali DP (rys. 1), spawanie stali TRIP nastręcza większych trudności. Twardość w strefie spoiny/ zgrzeiny i SWC wynosi zazwyczaj od 350 do $550 \mathrm{HV}$, a zalecenia technologiczne mające na celu ograniczenie możliwości powstania pęknięć są podobne jak

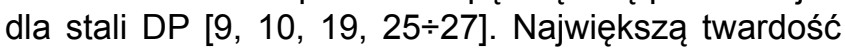
uzyskuje się w stalach z dodatkiem Si $[10,25]$. Po zastąpieniu krzemu przez aluminium hartowność stali i twardość maleją, lecz problemem staje się duża ilość wtrąceń niemetalicznych w strefie wtopienia oraz niebezpieczeństwo powstania miękkiej strefy w pobliżu linii wtopienia, będącej efektem nadmiernej stabilizacji ferrytu [26]. W odróżnieniu od stali DP, w stalach TRIP nie występuje problem obniżenia właściwości wytrzymałościowych złącza wraz ze wzrostem wytrzymałości stali, gdyż bainit nie jest wrażliwy na odpuszczanie.

Na podstawie doświadczeń własnych [27] stwierdzono, że dobrą spawalność wykazuje stal TRIP z krzemem częściowo zastąpionym przez aluminium. Próby przetapiania laserowego odcinków próbnych blach ze stali 0,24C-1,5Mn-0,9Si-0,4Al z mikrododatkami Nb i Ti prowadzono techniką głębokiego przetopienia $z$ wykorzystaniem lasera na ciele stałym, zintegrowanego ze zrobotyzowanym systemem do obróbki laserowej, zainstalowanym w Instytucie Spawalnictwa w Gliwicach. Poniżej przedstawiono wybrane wyniki przetapiania laserowego próbek $z$ energią liniową $0,051 \mathrm{~kJ} / \mathrm{mm}$. Podczas przetapiania następuje intensywne pokrywanie lica i grani warstewką tlenków manganu, krzemu i aluminium. Przyczyną intensywnego utleniania Mn, Si i Al jest prowadzenie procesu w atmosferze powietrza bez stosowania gazu osłonowego. Ponadto zaobserwowano obniżenie lica ściegu przetopienia, szczególnie od strony lica. Makrostruktura przekroju złącza charakteryzuje się kolumnowym ułożeniem kryształów, 
zgodnie z kierunkiem najszybszego odprowadzania ciepła, tj. prostopadle do osi przetopienia (rys. 5). Kryształy kolumnowe sięgają do środka obszaru przetopionego.

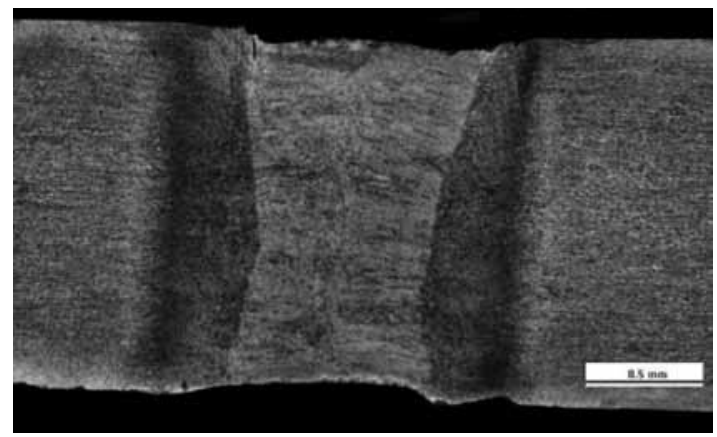

Rys. 5. Makrostruktura przetopienia stali TRIP wykonanego z energią liniowa $0,051 \mathrm{~kJ} / \mathrm{mm}$

Fig. 5. Macrostructure of the penetration area of TRIP steel made with heat input of $0,051 \mathrm{~kJ} / \mathrm{mm}$

Mikrostrukturę materiału rodzimego stanowi ferryt (F) o udziale ok. $60 \%$ (rys. 6a). W osnowie ferrytycznej rozmieszone są wyspy bainityczno-austenityczne (B-A) o zróżnicowanej wielkości. Udział austenitu szczątkowego wynosi ok. 15\% [27]. Największe ziarna fazy Y uległy częściowej przemianie martenzytycznej, tworząc skupiska M-A, mogące być przyczyną obniżenia udarności stali [28]. W strefie przejściowej pomiędzy materiałem rodzimym (MR) a strefą wpływu ciepła
(SWC) można zaobserwować zwiększenie udziału austenitu szczątkowego, ulokowanego w osnowie ferrytyczno-bainitycznej (rys. 6b). Wzrost udziału austenitu szczątkowego odpowiada temperaturowo wzbogaceniu austenitu w węgiel w zakresie międzykrytycznym $A_{c 1}-A_{c 3}$. Podobne zjawisko opisano w [10] i [26] w stalach TRIP typu C-Mn-Si i C-Mn-Al. Strefa wpływu ciepła charakteryzuje się drobnoziarnistą mikrostrukturą martenzytyczno-bainityczną z niewielkim udziałem austenitu szczątkowego (rys. 6c).

Wielkość listew w SWC rośnie wraz ze zmniejszaniem odległości od strefy przetopienia, co wynika $\mathrm{z}$ temperatury nagrzania stali $\mathrm{w}$ czasie spawania. Rodzaj mikrostruktury w strefie przetopienia nie zmienia się, z wyjątkiem widocznego zwiększenia wielkości listew (rys. 6d). Duża część obszarów listwowych ułożona jest równolegle do kierunku odprowadzania ciepła.

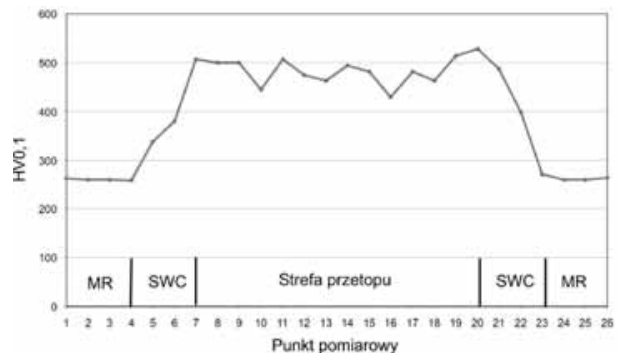

Rys. 7. Rozkład mikrotwardości wzdłuż przekroju poprzecznego w stali TRIP typu 0,24C-1,5Mn-0,9Si-0,4AI0

Fig. 7. Microhardness profile along the cross section of the 0,24C-1,5Mn-0,9Si-0,4AI TRIP-type steel
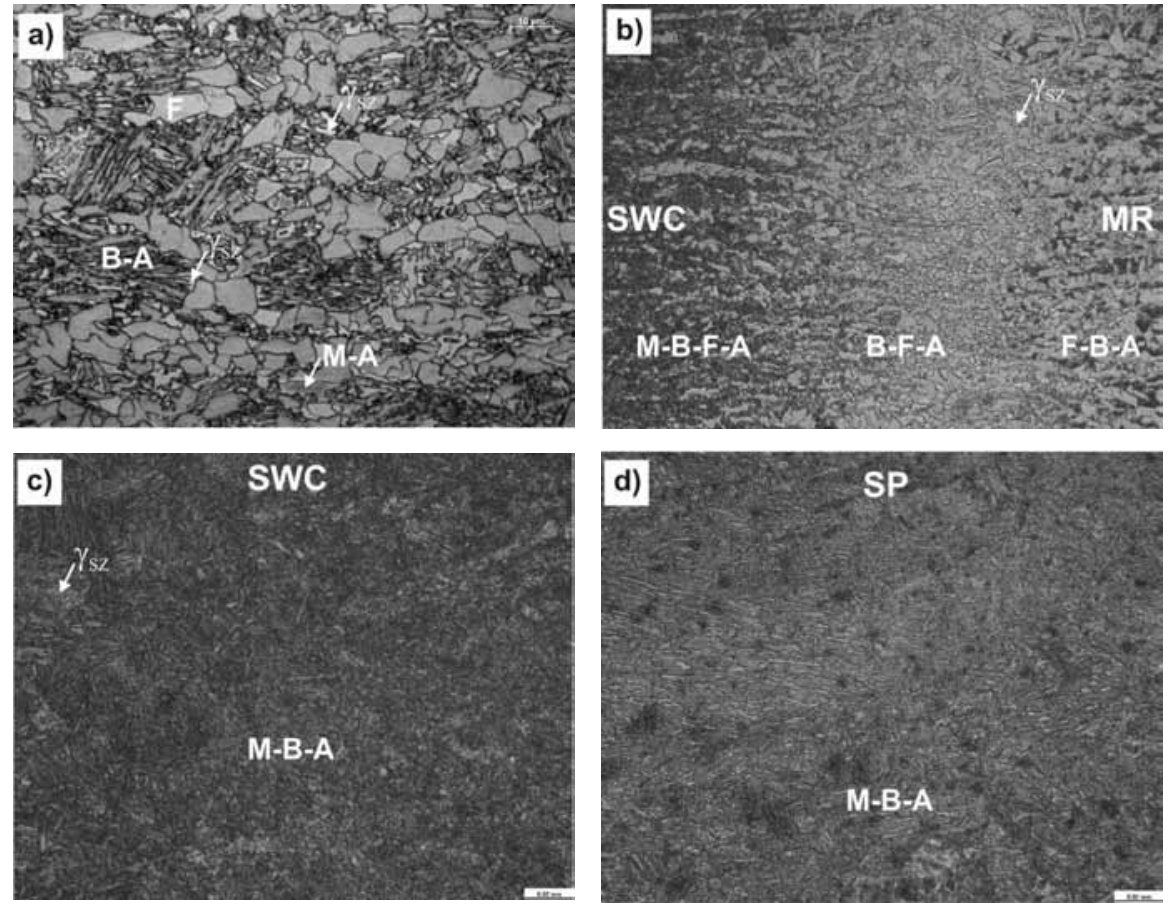

Rys. 6. Mikrostruktura materiału rodzimego (a), przejścia pomiędzy materiałem rodzimym (MR) i strefą wpływu ciepła (SWC) (b), strefy wpływu ciepła (c) i strefy przetopu (d) stali TRIP typu $0,24 \mathrm{C}-1,5 \mathrm{Mn}-0,9 \mathrm{Si}-0,4 \mathrm{Al} ; \mathrm{F}$ - ferryt, B - bainit, $\mathrm{M}$ - martenzyt, $\gamma_{\mathrm{sz}}$ - austenit szczątkowy

Fig. 6. Microstructure of the base material (a), intermediate zone between base material (MR) and heat affected zone (SWC) (b), heat affected zone (c) and fusion zone (d) of the $0,24 \mathrm{C}-1,5 \mathrm{Mn}-0,9 \mathrm{Si}$ 0,4AI TRIP-type steel; F - ferrite, B - bainite, $M$ - martensite, $\gamma_{s z}$ - retained austenite
Rozkład twardości wzdłuż przekroju poprzecznego próbki przedstawiono na rysunku 7 . Średnia twardość materiału rodzimego wynosi ok. $280 \mathrm{HV0,1}$. Na krzywej można zaobserwować wzrost twardości z ok. 280 do 500 HV0,1, co jest konsekwencją stopniowego zmniejszenia udziału ferrytu i wzrostu udziału struktur bainityczno-martenzytycznych. Największa twardość na poziomie ok. $500 \mathrm{HV0}, 1$ występuje w SWC, a następnie obserwuje się lekkie obniżenie twardości w strefie przetopu. Prawdopodobnie jest to związane z całkowitym rozpuszczeniem węglikoazotków $\mathrm{Nb} / \mathrm{Ti}$ i związanym z tym zanikiem umocnienia wydzieleniowego pochodzącego od dyspersyjnych cząstek [2]. 


\section{Spawalność stali CP}

W literaturze praktycznie brak jest do tej pory informacji na temat spawalności stali Complex Phase. Biorąc pod uwagę porównywalne stężenie dodatków stopowych oraz zawartość węgla jedynie nieco wyższą niż w stalach DP (rys. 1) można się spodziewać, że spawalność stali DP i CP powinna być zbliżona. $Z$ drugiej strony stale $\mathrm{CP}$ zawierają relatywnie duże stężenie mikrododatków $\mathrm{Nb}$ i Ti, tworzących dyspersyjne węglikoazotki. Dotychczasowe doświadczenia łączenia stali HSLA $z$ mikrododatkami o $R_{m}$ poniżej $600 \mathrm{MPa}$ wskazują, że nie powinno ono stwarzać problemów [1,22]. Wytrzymałość na rozciąganie stali CP jest jednak zazwyczaj wyższa od $800 \mathrm{MPa}$ [6]. Górka [2] stwierdził, że w przypadku spawania stali HSLA walcowanych termomechanicznie o $R_{m}$ ok. $700 \mathrm{MPa}$ i większej, umacnianych wydzieleniowo przez dyspersyjne cząstki węglikoazotków, o spawalności decyduje nie tylko równoważnik węgla i przemiany fazowe austenitu podczas chłodzenia, ale przede wszystkim trwałość faz umacniających i zmiana ich dyspersji. W wyniku szybkich cykli cieplnych dochodzi do zmian dyspersji i rozpadu faz umacniających, które w czasie chłodzenia wydzielają się ponownie w obszarze SWC i spoiny, lecz w sposób niekontrolowany. Podobnych zjawisk należy się spodziewać w stalach CP. Przesycenie roztworu stałego $\mathrm{Nb}$ i Ti może prowadzić do niepożądanych procesów starzeniowych podczas eksploatacji i spadku udarności złącza [2, 29].

$\mathrm{Na}$ podstawie dotychczasowych prób spawania laserowego stwierdzono, że możliwe jest uzyskanie dobrej jakości połączeń $w$ stali CP typu $0,08 \mathrm{C}$ $1,72 \mathrm{Mn}-0,56 \mathrm{Si}-0,35 \mathrm{Cr}-0,29 \mathrm{Al}-0,12 \mathrm{Ti}$. Na rysunku 8 przedstawiono makrostrukturę złącza uzyskanego przy energii liniowej $0,05 \mathrm{~kJ} / \mathrm{mm}$. Podobnie jak w przypadku stali TRIP uzyskano charakterystyczne, równoległe ułożenie dendrytów w kierunku materiału rodzimego o dużej pojemności cieplnej. Stal ta wykazuje jednak mniejszą skłonność do utleniania, co przekłada się na stabilność prowadzenia procesu.

Mikrostrukturę materiału rodzimego stanowi drobnoziarnista mieszanina ferrytu i bainitu o ziarnach fazy a wydłużonych w kierunku walcowania termomechanicznego (rys. 9a, 9b). Dodatkowo można zaobserwować drobne ziarna austenitu szczątkowego rozmieszczone równomiernie $w$ osnowie stali. W strefie wpływu ciepła dominuje drobnoziarnista struktura bainityczno-martenzytyczna (rys. 9c). Mikrostruktura martenzytyczno-bainityczna występuje także w strefie przetopienia (rys. 9d), lecz wielkość listew jest kilkakrotnie większa niż w SWC. Należy to wiązać z prawie całkowitym rozpuszczeniem cząstek węglikoazotków i przesyceniem roztworu stałego.

Szczegółowa identyfikacja mikrostrukturalna stali CP, a także pozostałych stali AHSS jest przedmiotem dalszych badań autorów, które obejmują także pomiary mikrotwardości, badania właściwości mechanicznych złączy oraz modyfikację parametrów spawania laserowego w celu uzyskania złączy o korzystnym połączeniu wysokiej wytrzymałości i gwarantowanej plastyczności.

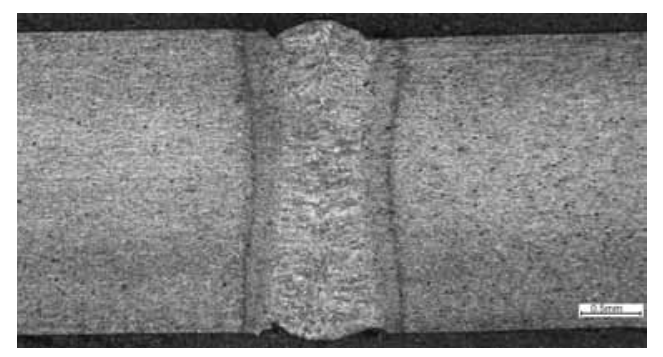

Rys. 8. Makrostruktura złącza spawanego laserowo ze stali CP wykonanego z energią liniową $0,05 \mathrm{~kJ} / \mathrm{mm}$

Fig. 8. Macrostructure of laser weld of $\mathrm{CP}$ steel made with heat input of $0,05 \mathrm{~kJ} / \mathrm{mm}$
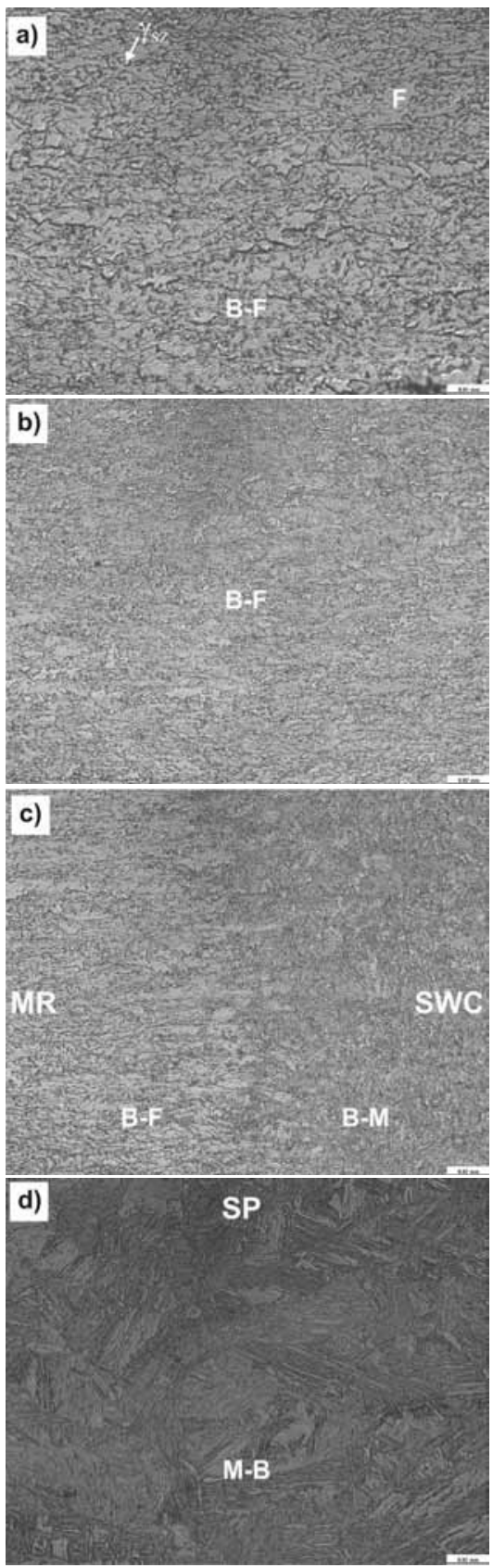

Rys. 9. Mikrostruktura materiału rodzimego $(a-1000 x, b-500 x)$, przejścia pomiędzy materiałem rodzimym (MR) i strefą wpływu ciepła (SWC) (c) i strefy przetopu (d) stali CP typu 0,08C-1,72Mn-0,56Si-0,35Cr-0,29Al$0,12 \mathrm{Ti} ; \mathrm{F}$ - ferryt, B - bainit, $\mathrm{M}$ - martenzyt, $\gamma_{\mathrm{sz}}$ - austenit szczątkowy Fig. 9. Microstructure of the base material $(a-1000 x, b-500 x)$, intermediate zone between base material (MR) and heat affected zone (SWC) (c) and fusion zone (d) of the $0,08 \mathrm{C}-1,72 \mathrm{Mn}-0,56 \mathrm{Si}-0,35 \mathrm{Cr}-0,29 \mathrm{Al}-0,12 \mathrm{Ti} \mathrm{CP}-$ type steel; $\mathrm{F}$ - ferrite, $\mathrm{B}$ - bainite, $\mathrm{M}$ - martensite, $\gamma_{\mathrm{sz}}$ - retained austenite 


\section{Literatura}

[1] Brózda J.: Nowoczesne stale konstrukcyjne i ich spawalność, Wydawnictwo Instytutu Spawalnictwa, Gliwice 2009.

[2] Górka J.: Właściwości i struktura złączy spawanych stali obrabianej termomechanicznie o wysokiej granicy plastyczności, Wydawnictwo Politechniki Ślaskiej, Gliwice 2013.

[3] Adamczyk J., Grajcar A.: Właściwości mechaniczne blach o strukturze dwufazowej ze stali konstrukcyjnej mikrostopowej obrobionej cieplnie i cieplno-mechanicznie, Inżynieria

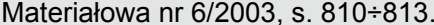

[4] Senkara J.: Współczesne stale karoseryjne dla przemysłu motoryzacyjnego i wytyczne technologiczne ich zgrzewania,

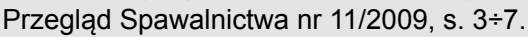

[5] Krajewski S., Nowacki J.: Mikrostruktura i właściwości stali o wysokiej wytrzymałości AHSS, Przegląd Spawalnictwa $\mathrm{nr} 7 / 2011$, s. $22 \div 27$.

[6] International Iron \& Steel Institute, Advanced High Strength Steel (AHSS) Application Guidelines, www.worldautosteel.org, September 2006.

[7] Grajcar A.: Struktura stali C-Mn-Si-Al kształtowana z udziałem przemiany martenzytycznej indukowanej odkształceniem plastycznym, Wydawnictwo Politechniki Śląskiej, Gliwice 2009.

[8] Adamczyk J., Grajcar A.: Blachy samochodowe typu DP i TRIP walcowane metodą obróbki cieplno-mechanicznej,

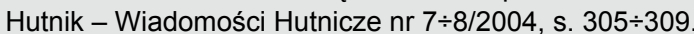

[9] Pichler A., Traint S., Hebesberger T., Stiaszny P., Werner E.A.: Processing of thin sheet multiphase steel grades, Steel Research International, vol. 78, 2007, s. $216 \div 223$.

[10] Amirthalingam M., Hermans M.J.M., Zhao L., Richardson I.M.: Quantitative analysis of microstructural constituents in welded transformation induced plasticity steels, Metallurgical

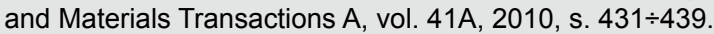

[11] Huh H., Kang W.J.: Electrothermal analysis of electric resistance spot welding processes by a 3-D finite element method, Journal of Materials Processing Technology, vol. 63, s. $672 \div 677$

[12] Gould J.E., Khurana S.P., Li T.: Predictions of microstructures when welding automotive advanced high-strength steels, Welding Journal $\mathrm{nr} 5 / 2006$, s. $111 \div 116$.

[13] Papkala H.: Zgrzewanie oporowe metali, Wydawnictwo $\mathrm{KaBe}, \mathrm{Krosno} 2003$

[14] Poggio S., Ponte M., Gambaro C., Adamowski J.: Badanie zgrzewalności oporowej stali AHSS DP600, Przegląd Spawalnictwa nr $12 / 2005$, s. $22 \div 25$

[15] Zadroga L., Pietras A., Węglowska A.: Zgrzewanie rezystancyjne punktowe blach typu DP450 i DP600, Biuletyn Instytutu Spawalnictwa $\mathrm{nr} 3 / 2007$, s. $49 \div 55$.

[16] Węglowski M.S., Stano S., Krasnowski K., Łomozik M., Kwieciński K., Jachym R.: Characteristics of laser welded joints of HDT580X steel, Materials Science Forum, vol. $638 \div 642$, 2010 , s. $3739 \div 3744$.
[17] Węglowski M.S., Stano S., Osuch W., Michta G.: Laser welding of DP steel - characterization of microstructure of steel and welded joint, Inżynieria Materiałowa 3/2010, s. 256 $\div 259$.

[18] Papkala H.: Nowoczesne sposoby zgrzewania oporowego blach ocynkowanych w produkcji seryjnej, Przegląd Spawalnictwa $\mathrm{nr} 2 / 1995$, s. 9 $\div 13$.

[19] Kowielski S., Mikno Z., Pietras A.: Zgrzewanie nowoczesnych stali o wysokiej wytrzymałości, Biuletyn Instytutu Spawalnictwa $\mathrm{nr} 3 / 2012$, s. $46 \div 51$.

[20] Pietras A., Papkala H., Zadroga L.: Zgrzewanie punktowe blach ocynkowanych z dodatkową powłoką organiczną typu solplex, Biuletyn Instytutu Spawalnictwa nr 6/2000, s. $50 \div 56$.

[21] Stano S.: Spawanie laserowe blach o zróżnicowanej grubości przeznaczonych na półfabrykaty karoserii samochodowych typu tailored blanks. Prace prowadzone w Instytucie Spawalnictwa, Biuletyn Instytutu Spawalnictwa nr 2/2005 s. $24 \div 28$.

[22] Lisiecki A., Mańka J.: Spawanie blach ze stali S420MC o podwyższonej granicy plastyczności laserem diodowym dużej

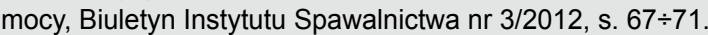

[23] Klimpel A.: Technologie laserowe w spawalnictwie, Wydawnictwo Politechniki Śląskiej, Gliwice 2011.

[24] Stano S.: New solid state lasers and their application in welding as generators of laser radiation, Welding International, vol. 3, 2007, s. 809 $\div 813$.

[25] Cretteur L., Koruk A.I., Tosal-Martinez L.: Improvement of weldability of TRIP steels by use of in-situ pre- and post-

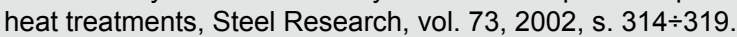

[26] Amirthalingam M., Hermans M.J.M., Richardson I.M.: Microstructural development during welding of silicon and aluminum based transformation induced plasticity steels - inclusion and elemental partitioning analysis, Metallurgical and Mate-

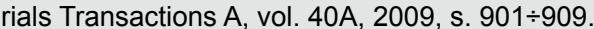

[27] Grajcar A., Różański M., Stano S., Kowalski A., Grzegorczyk B.: Effect of heat input on microstructure and hardness distribution of laser welded Si-Al TRIP-type steel, Advances in Materials Science and Engineering, vol. 2014, 2014, doi.org/10.1155/2014/658947, 8 pages.

[28] Mroczka K., Zielińska-Lipiec A., Ratuszek W., Tasak E.: Identyfikacja składników strukturalnych w strefie wpływu ciepła w stalach o dużej wytrzymałości, Hutnik - Wiadomości Hutnicze $\mathrm{nr} 7 \div 8 / 2004$, s. $396 \div 399$.

[29] Gruszczyk A., Griner S.: Właściwości połączeń spawanych i zgrzewanych stali obrobionych termomechanicznie, Prze-

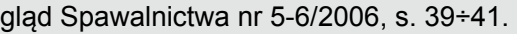

\section{Miesięczne i roczne spisy treści oraz streszczenia artykułów opublikowanych w Przeglądzie Spawalnictwa są dostępne na stronie internetowej:}

WWw.pspaw.ps.pl 